\title{
Crossing the Gap between Indigenous Worldview and Western Science: Millet Festival as a Bridge in the Teaching Module
}

\author{
Chia-Ling Chiang ${ }^{1}$, Huei Lee ${ }^{1}$ \\ ${ }^{1}$ Department of Curriculum Design and Human Potentials Development, National Dong Hwa University, Hualien, \\ Taiwan \\ Correspondence: Chia-Ling Chiang, Department of Curriculum Design and Human Potentials Development, National \\ Dong Hwa University, 1, Dashueh Rd., Hualien, Taiwan
}

Received: August 4, 2015 Accepted: August 20, 2015 Online Published: August 27, 2015

doi:10.11114/jets.v3i6.1002 URL: http://dx.doi.org/10.11114/jets.v3i6.1002

\begin{abstract}
The worldview within indigenous people's traditional knowledge and western science can be a world of difference. In order to help indigenous students cross the gap and develop a sense of cultural identification. Taking Bunun, one of the Taiwanese indigenous tribes, as our subject, this study aims to develop a teaching module through Bunun's Millet Festival and implement this module to analyze students' performance. To have a better understanding of the worldview of Bunun, we had individual interviews with tribal elders and compared the collective materials with literature. Millet Festival is a significant ceremony for Bunun for passing important cultural custom and knowledge. Thus, taking Millet Festival as centerpiece of this study, we tried to connect traditional indigenous knowledge with school science education during Reclaiming Festival, Seed Sowing Festival, Ear-Shooting Festival, Garnering Festival and by making tribal elders assist with school teacher in class. The result shows that this teaching module not only provides abundant materials related to scientific subjects, but also makes the students appreciate the value and meaning of their own culture more. In addition, they would learn to respect the tribal elders sincerely and therefore the cultural inheritance would be rebuilt.
\end{abstract}

Keywords: Bunun, Millet Festival, traditional knowledge, worldview

\section{Introduction}

\subsection{The Difficult Position for Indigenous Students in Science Learning}

For a long time, Western science has been considered the only "science" for its outstanding accomplishments and unique understanding and observation of nature. Along with the influence and expansion of colonialism, European science spread to the world and became the main stream. However, as the reflection on colonialism grows, people started to reflect on the phenomenon of science supreme (Aikenhead, 2011). Also, we could not deny that in the recent two decades, the revolution on science curriculum has been focusing on materials for teaching and the cultivation of teachers, which are derived mainly from western science and attempt to enculturate all students into the value system of Western science (Aikenhead, 2001). Yet this attempt neglects indigenous knowledge that is based on tribal living experience (Guo, 2007). Many scholars (e.g. Chinn, 2007; Fleer, 1997; Hale, 1994; McKinley, 2005, 2007; Sutherland, 1998) pointed that due to the differences between indigenous worldview and that of the western world, students may not be able to find support from western worldview while they are asked to identify with western science. This may lead to a serious problem in cultural adaptation and frustration in learning science. Therefore, indigenous students could feel alienated from science learning and left out from further learning. To solve this problem, Aikenhead (2008) suggests to help indigenous students' science learning from an explicit cross-cultural perspective and a perspective on the relevant world of everyday events or issues.

There are diversified ethnic groups in Taiwan, and indigenous group is one of the branches of Austronesian. Culture in different indigenous groups can be various and unique, from speaking language, social system to traditional customs. So far, there are fourteen native indigenous tribes in Taiwan. With the mighty torrent of history and rapid change of ecological and social environment, these tribes developed unique strategies to adjust which became the traditional ecological knowledge passed on to today. Nevertheless, the traditional knowledge of Taiwanese indigenous tribes is now endangered and might be lost. In the past, it is passed on through various activities and events like worship 
ceremony, farming, weaving, hunting, cooking and so on. While in recent decades, due to the interference of school education with main stream culture and children's spending much time in school, indigenous students merely have chance to access to traditional knowledge from home or festivals that became sightseeing and rare (Tsi, 2006). Hence, indigenous students not only feel alienated to traditional knowledge but also grew less identified with traditional culture.

\subsection{Worldview and Science Education}

A worldview is a culture's collection of thoughts, beliefs, and values. In ethno-semantics, it is the reality through which a culture understands its human-environment interactions and includes related images and assumptions symbolizing the creation, use, and morality behind the behavior and decisions of individuals (Kearney, 1984). In short, a certain worldview provides a framework for the way of a person's behavior and thoughts or of how a whole community makes sense of life and the world (understood to include the entire universe) in its most significant aspects and dimensions (Irzik \& Nola, 2009).

As Cobern and Loving (2001) suggested, every culture has its own scientific knowledge, just that it is not necessarily called "science." This way of looking into the world derived from the interaction between human and environment, thus determines the way of how people look into reality along with their behavior and insights. This is what Kearney (1984) defined "worldview." For instance, Orchid Island's Tao people separate fish into different categories such as old fish, male fish and female fish according to its eaters and its texture. This categorization is at the same time accords with social classes while European zoologists distinguish fish into Chondrichthyes and Osteichthyes according to its physical structure in order to find the evolutionary filiation. These ways of categorization have their own consideration and function, and it is unfair to judge which is better. Knowledge itself and way of thinking originated from the creativity of human, and therefore different belief and value affect the way how people work and gain their knowledge. Thus, understanding cultural and ethnic difference upon looking at and dealing with natural phenomenon is essential, so is the understanding of the worldview based on relationship between individual and nature.

Students from different communities can be influenced by their living environment and culture, and develop a far different worldview from western scientific one. Because of this difference, indigenous students may feel strange toward western scientific knowledge which includes information mostly abstract, symbolic, yet needs specific definition. Consequently, they feel difficult to adapt, and then refuse to learn. Finally, they become less motivated and underperformed. Worst of all, a wall that splits indigenous knowledge and western knowledge is then built and hard to break. In addition, the teaching materials that cannot be connected with the students' worldview might lead to a difficult learning situation and make students unable to work out the best of their learning (Hale, 1994). Similarly, Chang, Lee and Yen (2010) pointed out that if science education does not take seriously the different cultural contexts of students' worldviews, it may be setting up barriers to learning. Also, Ogawa (1989) and Jegede and Okebukola (1991) also agreed that non-western countries might lose their own cultural identity if the school science education only focused on western scientific knowledge. To make science learning meaningful to indigenous students, educators need to design and collect teaching materials from indigenous students' daily life and living environment.

\subsection{Lis-an (Ceremony), Samo (Taboo) and Science Leaning}

To probe into indigenous traditional knowledge, we have to have a better understanding of indigenous worldview. However, a worldview might be obscure, and even people living in his own culture may not be clearly identify or define it. In order to be close to this obscure concept, we tried to include indigenous festivals into our teaching module, for which contain deep-rooted worldview. Therefore, we could through ceremonial rituals and taboos. As Yang (2006) mentioned, the spirit and taboo of Bunun rituals reach far to Bunun people's social standard, emotion, and structures of feeling. Also, Bunun rituals show a distinctive way of understanding the world from Bunun's traditional culture.

Human beings come up with standard rules by observing nature. In order to pursue good luck and keep clear of evils, they make social standard by establishing the many taboos. Upon those unknown and unpredictable, they count on spirits and even try to control the weather and domestic animals by holding ceremonies and developing incantation. Lee, Chiang and Lin (2011) discovered that to survive in the merciless mountains, Bunun people pay much attention to surviving knowledge. The more one know, the more powerful he is. Therefore, he can become the tribe leader and lead the tribe to enrichment and prosperity.

For human beings, ceremonial ritual is a kind of language, a method, and a divine way to communicate with god, from which people gain the power to agreed and support themselves. Also, they discover balance and compromise to nature. In addition, it is the core of a culture. Through ceremonial rituals, the power of men is collected and establishes cohesive forces. On the other hand, for community without written words, ritual is an essential carrier for passing on traditional culture and knowledge. Like Bunun's Ear-Shooting Festival, except for praying good luck with hunting, adult male members hang ears of the animals on tree branches to teach young kids how to shoot, encouraging them to 
be outstanding hunters.

As for how to improve the science learning of indigenous students, there is an agreement reached by many pioneers (Aikenhead, 2008; Chinn, 2007; McKinley, 2007) from a position more closed to indigenous children. In the past, western science was the only knowledge, but it becomes merely a part of the subjects in science education nowadays. As Lee (2013) mentioned, many of the scientific activities for exploring Taiwanese indigenous wisdom are firstly established from the cumulated past experience of indigenous people and their way of using implements, then provide an explanation with western scientific terms. Although these researches might include the internal background and meaning of certain knowledge and skill, the external theory and explanation are still addressed by the abstract scientific terms. Since these theories do not provide the connection among traditional knowledge, taboos and ceremonial rituals, it is difficult for people to reach for a deeper worldview of indigenous culture.

Therefore, many scholars (e.g. Aikenhead, 2001, 2008; Chinn, 2007; Irzik \& Nola, 2009; McKinley, 2007) suggest that how to let students learn traditional wisdom based on indigenous worldview while learn to understand western scientific point of view and way of knowing is a current goal that needs more effort. Rather than requiring students to build a new and western worldview, the integration of western science and indigenous worldview should be bringing western science into indigenous children's life. Based on this way, teaching materials should be tracking the students' culture and be modified to adapt indigenous students. In other words, through this way teachers could present both traditional cultural knowledge and western scientific knowledge at the same time, and so to help students' learning western science without making them lose their own cultural identity.

Despite the fact that ritual plays an important role for Taiwanese indigenous tribes, it is especially divine and significant to Bunun which has the most rituals among other Taiwanese indigenous tribes. Among all of the rituals, a series of Millet Festival events are of most importance. Because not only that millet is the main food for Bunun people, but also that Bunun people's perception of time and annual events are based on the growing of millets. A year begins with reclaiming and seed- sowing and ends with a series of celebration during and after millet garnering. Due to the reason that Millet Festival is a vital core of the culture of Bunun festivals and rituals, we developed a set of learning activities integrated with a series of Millet Festival. Also, we expect to establish a scientific teaching module that is more close to Bunun culture and worldview. Hence, we had Bunun students as our participants and further examined the performance of these students.

\section{Method}

In the way of qualitative research, this study collected information through individual interview, document analysis and collaborative action research. There were three phases within this research. Firstly we probed into Bunun worldview and Bunun people's understanding of the universe through document analysis and interviews with tribal elders. Taitung County's Haiduan Township has been the main area of the activities of Bunun communities and there are abundant sources for discovering Bunun tribes' traditional culture.

Based on the interview, we tend to link Bunun worldview with western science and to design a scientific teaching module centering on Millet Festival. Because of the limitation of time and human sources, we selected four of the main festivals within Millet Festival to apply to the teaching topics. According to the suitability for current primary school science learning, we chose Reclaiming Festival, Seed-sowing Festival, Ear-shooting Festival and Garnering Festival as the teaching materials.

The third phase was to progress actual teaching practice and to observe the performance of students. The subjects are 4th to 6th grade students in a local primary school where the students are mainly Bunun. Duration is about two months, teaching module applied once every two weeks, with 2 to 3 hours every time. In Bunun tradition, tribal elders play an important role in passing on knowledge to young generations, so we invited tribal elders to the classroom, providing instruction with school teachers. The first hour was lectured, worked, shared and explained by both teachers and tribal elders. During the second and third hours, teachers guided students to through discussion, explanation and operation, and then apply western science into indigenous knowledge. Finally, the students were asked to write a feedback sheet. Via the mixed instruction, students could go beyond either traditional knowledge or western science to contemplate on the value of traditional knowledge and the relationship between human and nature.

\subsection{Research Context}

The subject Bunun tribes are located in Central Mountain in Taiwan. Most Bunun in the subject area belong to Isibukun, the largest community among the six large communities of Bunun (Bima, 1998). Bunun people have been living there for more than two hundred years, so there are abundant sources of Bunun traditional culture. This area has been an essential area for cultural research on Bunun community. Tribes in this area have close connection with each other, and mostly are relatives. Whenever there is an activity, they would invite each other to attend. 


\subsection{Elders}

We interviewed ten of the tribal elders. Though they had different jobs, they all grew up in the tribes and all passionate about Bunun cultural conservation. Some of them have been long-term subjects of academic organizations, so are no strangers to academic interview.

\subsection{School, Teachers and Students}

This study collaborated with a tribe primary school, and a teaching module was designed and applied to actual classroom. Subjects are 29 students from forth to sixth grade. This primary school has been long endeavoring to the inheritance of Bunun culture and has been supported by government to establish activities for conserving indigenous culture and language. Despite the teaching materials on ethnic plants instructed in Bunun language and a website for teachers and students to learn about Bunun culture, teachers could only provide cultural lessons as extracurricular activity. The reason is that these materials have not yet been integrated into formal teaching materials. Thus, traditional knowledge and science knowledge in textbooks still cannot be connected. Because of this, this study aims to strengthen the connection between the two of them by designing a specific teaching module.

There were Bunun teachers and non-Bunun teachers in this school. Due to the great loss of indigenous culture, young Bunun teachers were not familiar with traditional culture and knowledge. Thus, we chose to work with a senior Bunun teacher who is more familiar with ceremonial rituals and Bunun festivals.

\subsection{The Series of Bunun Millet Festival}

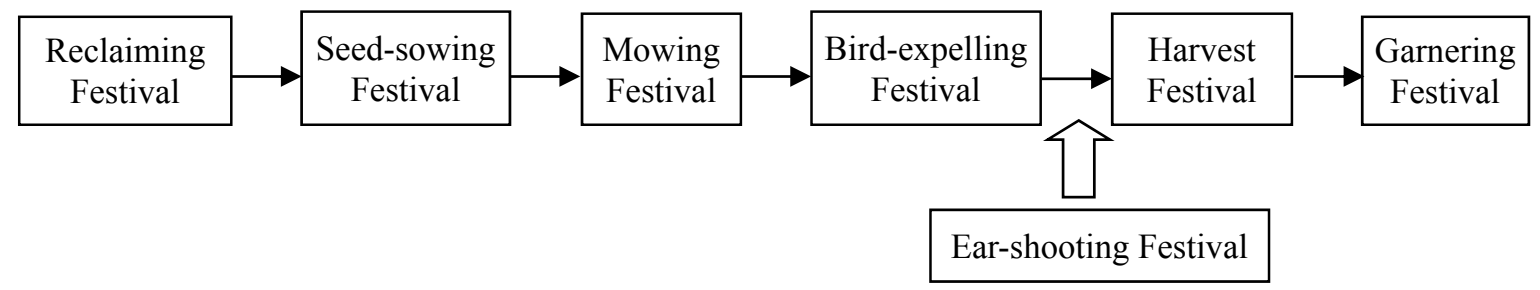

Figure 1. The series of Bunun Millet Festival

Bunun's Millet Festival is not a single festival; on the other hand, it includes a series of complicated events. Well-known events are shown as Figure 1.

Except Ear-shooting Festival, others are followed by the planting and growing of millet. Since most animals are in hibernation in winter, and people are busy collecting crop of millet in June, the best time to go hunting is April and May, the time for holding Ear-shooting Festival. During this period of time, most wild animals have given birth to their babies, so Bunun people could go into the mountains and hunt prey for celebrating Ear-shooting Festival (Ming, 1989). Though Ear-shooting Festival does not belong to Millet Festival, it is still an important cultural activity for Bunun. In addition, the time for Ear-shooting Festival is closely related to the planting of millet, so we decided to include Ear-shooting Festival into this study.

\section{Results}

\subsection{The Bunun Worldview: Human in Nature}

Bunun in its own language means "human." Traditionally, Bunun people divide the universe into three worlds, "Nature" (dihanin), "Spirit" (hanido) and "Human" (bunun). The ancestors of Bunun believed that they were the only "Human" in the universe while others are either different species or spirits (Vava, 2002).

\subsubsection{Human (bunun)}

Bunun people divide human into three parts (as shown in Fig.2). The first part is Logbo, physical body given by mother. The second part is hanido, internal spirits on right shoulder and left shoulder. Spirit in left shoulder is "makwan hanido," which induces people to be selfish, violent or hurt others; while spirit in right shoulder is "mashia hanido," which guides people to be generous, kind and friendly. The third part is "isang," which determines every individual's inclination toward "makwan hanido" or "mashia hanido." According to this division, Bunun people consider right hand side as respectful, so they will always use their right hand to toast and pass over things, showing their sincerity toward others. "Isang" represents personal will, so as one grows up, isang will also grow stronger and gives everyone different characteristics (Huang, 1989; Yu \& Ou, 2002). As a result, in additional to physical appearance, one also possesses the power of both good and evil. This is symbolic to human life that one has to continuously struggle between good and evil. In order to suppress the evil power, one has to follow the taboos so as to manifest good deeds and morality. What's more, one still has to make decision between good and evil through personal experience and wisdom (Vava, 2002). 


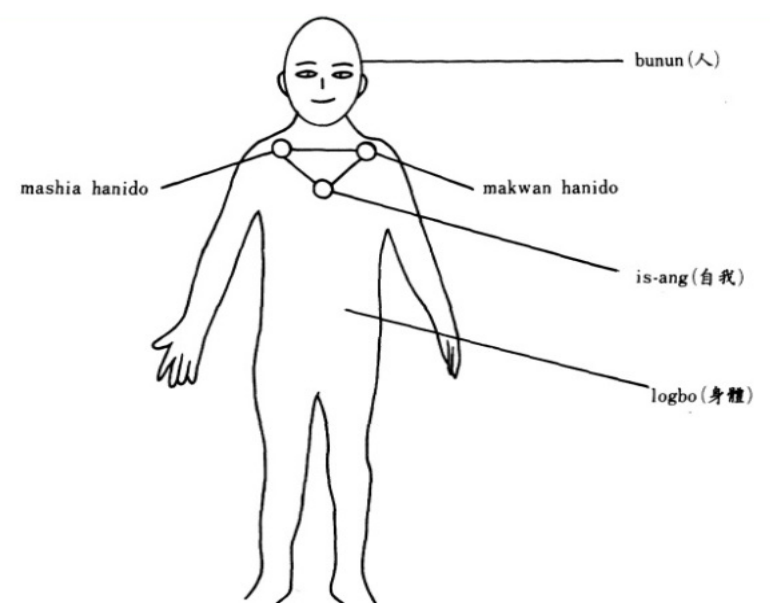

\subsubsection{Spirit (hanido)}

Figure 2. The Concept of Human for Bunun (Huang, 1989)

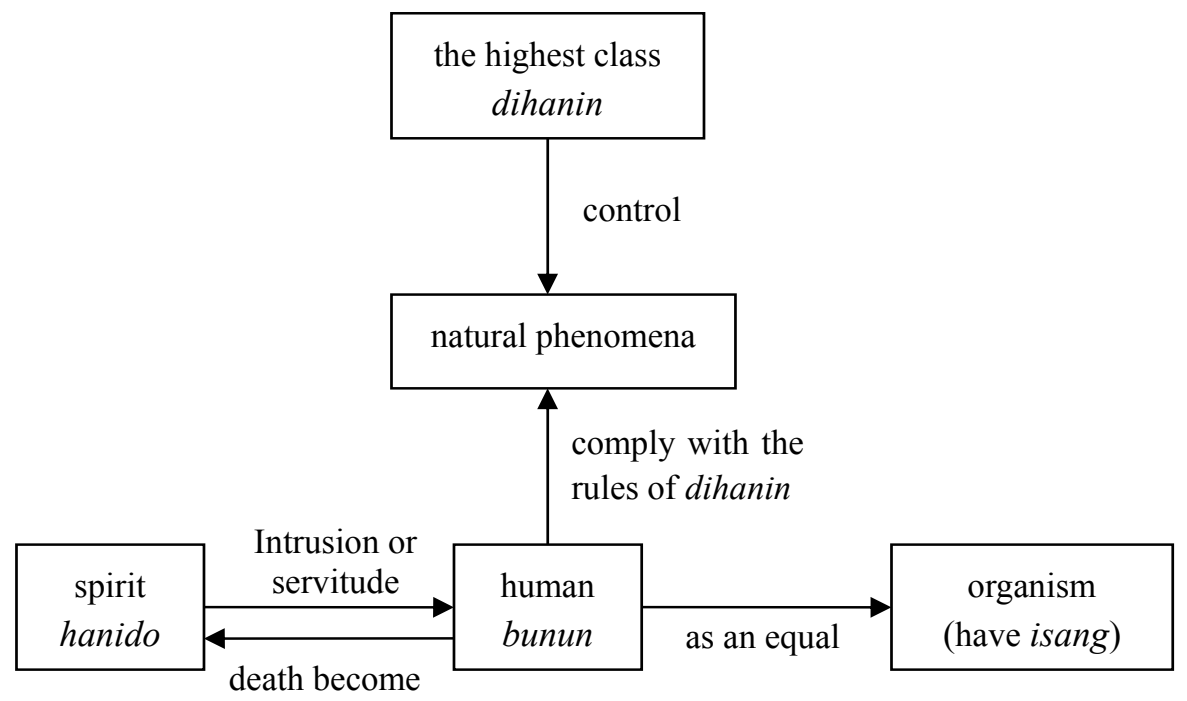

Figure 3. Bunun Worldview and Natural Ranks (Lee, Chiang, \& Lin, 2011)

"Hanido" can be a spirit of anything in Nature, such as animals, plants, lands or stones. This is specifically an internal power within each of the natural objects and it can be either strong or weak within different objects. When a creature dies or an object disappears, hanido within it may leave, transform or vanish (Huang, 1989).

Bunun people also believe that human can be able to communicate with other natural spirits, even manipulate them with the strong power of human kind. However, other powerful spirits may do harm to human beings as well. Every "hanido" is equal, and can either help or harm people. The spirits are always around at any time and any place. Based on this concept, Bunun people believe that everything in nature is equal and has its own value. Since there is no one superior or inferior, men have to respect everything else around the world (Vava, 2002).

For Bunun people, the mountains can be alive because there is every kind of Hanido within animals, plants or stones. Some are wild and unknown, while some are the spirits of objects accidentally died, they might be dangerous to human beings. The most important one among these Hanidos are the spirits of the ancestors, for they can protect Bunun people and bring good luck. Before going into the mountains and hunting, they would firstly pray with wine and cigarettes, letting the spirits know that they are going hunting to prevent from offending the spirits. Through this way, they can also invite the spirits of the ancestors to protect them. During the interview, some elders mentioned that villagers had experiences encountering some of the spirits and being troubled.

Hence we could clearly see that Hanido plays a very important role in Bunun tribes. They not only existing anywhere and anytime, but living with human beings. Some of them are men's friends while some of them may cause harm. To 
not offend these Hanidos, Bunun people carefully follow taboos to avoid being harmed. Unusual events happened in life are believed to be Hanido playing tricks. But the elders think that there is no need to especially afraid of Hanido as long as men sincerely respect them. Basically, Hanido represents some kind of mysterious power or phenomenon. Therefore, Bunun people set many taboos as "teaching materials" for future generations to behave carefully and avoid being hurt by Hanido.

\subsubsection{Nature (dihanin)}

The concept of "dihanin" is more obscure since it technically means "heaven" while traditionally means powers of heaven such as wind, rain, thunder, lightning, moon, sun, stars and so on (Huang, 1991). On the other hand, it can also be considered as "god" who created the whole universe. In additional to natural phenomenon, the relationship between individuals, human beings and universal objects, and fate are all controlled and manipulated by dihanin. Dihanin also signifies the core value of morality for Bunun. Therefore, men will be punished because of their wrongdoing or not fulfilling ceremonies. One of the elders, Cina mua, interviewed recalled that parents always warned kids to behave properly; otherwise, they might be punished by dihanin. To conclude, dihanin is a comparably abstract idea and there is no concrete shape of it. It is the moral standard of human society, and the natural law of the universe. Everyone has to obey its law, and pray for its protection and help through ceremonial rituals, so as to avoid disaster and bring good luck.

\subsection{The Teaching Module}

Because of the complexity of the series of Millet Festival, and due to the fact that not everything can be applied to primary school learning, we chose to only look at Reclaiming Festival, Seed-sowing Festival, Ear-shooting Festival and Garnering Festival and implement these four specific festival into our teaching module.

\subsubsection{Reclaiming Festival: Best Way to Determine Seasonal Change}

Traditionally, millet is the most vital production for Bunun tribes. Tribal elders claimed that during the process of growing millet, time for seed-sowing is especially important. If the millet seed is not sowed too late, the growing and Garnering of it might be seriously affected. The warm weather in March and April is the best time for millet to sprout, so Bunun people have to spread the seeds before Spring. Because of the calculation of Bunun calendar, when to open the ground and when to sow seeds become the most vital issues that Bunun people concern.

Isibukun Bunun's traditional calendar divides a year into ten months. Reclaiming Festival is held in the tenth month (Vava, 1997). Researcher had observed the stars with tribal elders, and the elder mentioned, "We would especially look for "bonok," a V-shape start sign, at around 4 to 5 in the early morning when opening season is close. It is usually located at the spot we see sunset (Note: South-west). Elders would get up very early in the morning of October and November, and as long as they see this start sign, they know it is time to get prepared." From the perspective of western science, the V-shape start sign is called as Taurus. For the time that Taurus goes down to the west to the domestic mountain top is exactly around October. Thus we could conclude that Bunun people have observed the circular regulation of starts and its relationship with seasonal change. Therefore, we try to implement the worldview of "Dihanin," the natural law, into teaching materials and link it to the chapters on constellations and their regular movement. Finally, students would learn how their ancestors tell the seasonal change through observation of constellation.

\subsubsection{Seed-Sowing Festival: Symbolic Meaning and Ecological Value of Soapberry}

Bunun people are living in the mountains, where there is abundant of plants. Therefore, Bunun people's life experience can never be alienated from plants. During the ceremonial ritual, some plants would be used symbolically for praying. For example, during Seed-sowing Festival, tribal elders would put the fruit of soapberry onto silver grass pole, stick it to the ground, and then pray and communicate with the spirits of ancestors. As being asked why is it especially soapberry and silver grass pole, the elders said, "To make a wish that the stem of millet can grow to be something as strong as a silver grass stem, and that the millet can be as large as soapberry." In other words, this is to pray for garnering for the coming year. Based on this idea, we implement the worldview of "praying for bless through ceremonial ritual" into chapters relevant to the categorization, structure and function of plants, letting students learn all these from observing the features of soapberry firstly.

Besides ceremonial rituals, soapberry is a common cleaning supply in traditional Bunun life. Hence, this topic teaches students the function of soapberry in traditional indigenous life. Also, the students will realize that using soapberry as cleaning supply is just in accordance with the eco-awareness nowadays.

\subsubsection{Ear-Shooting Festival: Gunpowder Prescription and Ecological Conservation}

Bows and arrows are early tool for hunting, and later there were guns. The production of gunpowder is thus the primary work for Bunun people. Yet in the past, how did they produce gunpowder that is much easier to purchase today by using 
natural sources? According to one of the tribal elders,

"...there is a shelf in chicken coop on which chickens can move around. The excrement of chicken will be going to the ground through the chink on the shelf. After one or two years, the excrement on top will be put aside and the soil underneath will be taken...and then the soil is washed with water, after that...this collected water will have a thick smell of excrement. Then we cook this water, keep cooking, keep stewing, till it becomes almost solid, a bit like gel. We put out the fire, waiting until it gets cold. Then there is nothing liquid in the pot, there is only some kind of white powder inside.

... and there is another kind of powder...that our ancestors could never buy. So our ancestors would climb up to the mountains looking for the largest and oldest hot spring. When the hot spring flowed through the stone, there would be sulfur solidified on the stone. They scraped off the sulfur and make it sun-dried till it is completely dried. Finally, they picked all the impurities out of the powder, leaving only yellow powder.

... Our ancestors would chop down a kind of tree, of which the fruits taste salty. Then they burned the chunk till it became charcoal, and chop, chop, chop, chopping it into powder. It is this black powder, but not any kind of tree can be turned into charcoal, it must be this...The ingredients of gunpowder are this black powder mixing with white powder extracted from chicken excrement and yellow powder obtained from hot spring. Only these three mixed together could result in ignition."

From western science's point of view, the white powder extracted from chicken excrement contains nitre, the main ingredient of yellow powder scraped off from stones beside the hot spring is sulfur, and the black powder is from the nutgall tree. These three are the main ingredients for making gunpowder. With this knowledge, textbook chapters on principle of combustion can thus be connected to the indigenous life and tradition.

On the other hand, there are serious rule and taboos for hunting and the object to hunt in Bunun culture. For instance, animal-hunting is not allowed during the breeding season. Also, hunting activities are not allowed when the number of animals decreased. They have to wait until the number increased. The elders said, "This is the rule of our ancestors."

“...Usually in order to prolong the existence of animals, we couldn't go hunting in the mountains this time when does are pregnant. We must wait until the fawn baby is born. What's more, the hunter would go to the mountains and take a look at his prey. If the antler is still small, we have to wait until it grows large. Usually each family has their own hunting field. To portion out the food, the elders set rules for the family hunting field. The hunters could not step beyond the boundary. Then the elders in each family would discuss how to maintain the number of animals. They could not kill all the animals at one time."

From the point of view of ecology nowadays, the rules and taboos include the modern concept of sustainable conservation. In Bunun's worldview, human being is not the master of the universe, and is equal to any other animals. There is no one superior and no one inferior. Therefore, human should not be near-sighted and hunt the animals excessively. This worldview of "obeying the law of Dihanin" and "Taboos set because of Hanido" is close to modern concept of conservation, thus can be applied to textbook chapters on eco-conservation.

\subsubsection{Garnering Festival: Production and Significance of Millet Wine}

Garnering food is rather important for many communities. When Bunun people store the sun-dried millet crop to the barn, they would hold Garnering Festival. During this festival, millet is the indispensable offering. According to one of the tribal elders, the production process of Millet Wine is as follows:

...there was no fuel gas in the past, so our ancestors burned wood to steam millet, which took a whole day...then mashed and hulled mukun (Formosa Lambsquarters), and added it into the pot. But you must wait until the cooked millet gets cold, and then you put into mukun - mukun looks like the spikes of rice - then seal it. Besides this process, because mukun does not ferment very well, we have to ask someone who is healthy and has no bad tooth to chew the millet, mixing the saliva into the cooked millet, then spit it out into the millet prepared to make wine. But we don't do that now, that is an ancient method...Because mukun does not ferment well, so our ancestors needed to add saliva. Without saliva, millet wine would taste bitter. With saliva, the wine tastes sweeter, sweet taste.

For the design of teaching module, through introducing mukun and its relationship with seasonal change, we could also link it to ferment mechanism. Through this way, kids would think more about the meaning of traditional Garnering Festival and understand that only working hard on plowing and sowing could lead to Garnering. Only with the garnering of production, there could be extra food to be stored and garnered and made into wine. Otherwise, there would not be any extra food to store, not even mention making millet wine. Hence, Work-Garnering-Wine has a close cause-and-effect relationship with each other. Through Garnering Festival, students would realize why hard working is an upholding value for Bunun people. According to the tribal elders, indigenous people only drink wine when there is a 
festival or when friends come to visit. Thus, the students learned their own traditional drinking culture rather than following Han people's stereotype that indigenous people are used to be alcoholic. This teaching module not only lets students know more about how to make wine and the ferment mechanism during the process, but also let them have a better understanding of the drinking culture. In addition, students would learn the significance of working hard.

This study aims to develop a teaching module centered on ceremonial festival and founded on Bunun worldview (see Table 1).

Table 1. The connection between Millet Festival, worldview and teaching goals

\begin{tabular}{|c|c|c|c|}
\hline Festival & Topic & Goal & Worldview \\
\hline \multirow{2}{*}{$\begin{array}{l}\text { Reclaiming } \\
\text { Festival }\end{array}$} & \multirow{2}{*}{$\begin{array}{l}\text { Constellation and } \\
\text { Star Movement }\end{array}$} & $\begin{array}{l}\text { Learn how ancestors tell seasonal } \\
\text { change }\end{array}$ & \multirow{2}{*}{ Obeying Dihanin's Natural Law } \\
\hline & & $\begin{array}{l}\text { Learn the relationship between } \\
\text { constellation and seasonal change }\end{array}$ & \\
\hline \multirow{3}{*}{$\begin{array}{l}\text { Seed-sowing } \\
\text { Festival }\end{array}$} & \multirow{3}{*}{$\begin{array}{l}\text { Ethno-Plant: } \\
\text { Soapberry }\end{array}$} & Learn to tell the features of soapberry & \multirow{3}{*}{$\begin{array}{l}\text { Praying for Dihanin's Bless } \\
\text { through Festivals }\end{array}$} \\
\hline & & $\begin{array}{l}\text { Learn the significance of soapberry in } \\
\text { the festival }\end{array}$ & \\
\hline & & $\begin{array}{l}\text { Learn the cleaning function of } \\
\text { soapberry }\end{array}$ & \\
\hline \multirow{3}{*}{$\begin{array}{l}\text { Ear-shooting } \\
\text { Festival }\end{array}$} & \multirow{3}{*}{ Gunpowder } & $\begin{array}{l}\text { Learn to know the ingredients used to } \\
\text { make gunpowder }\end{array}$ & \multirow{3}{*}{$\begin{array}{c}\text { Obeying Taboos set to respect } \\
\text { Hanido }\end{array}$} \\
\hline & & Learn the ignition of gunpowder & \\
\hline & & $\begin{array}{l}\text { Learn traditional knowledge and } \\
\text { taboos for hunting }\end{array}$ & \\
\hline \multirow{2}{*}{$\begin{array}{l}\text { Garnering } \\
\text { Festival }\end{array}$} & \multirow[b]{2}{*}{ Millet Wine } & Learn the mechanism of fermentation & \multirow{2}{*}{$\begin{array}{l}\text { Following the rules under } \\
\text { Dihanin }\end{array}$} \\
\hline & & $\begin{array}{l}\text { Learn the process and meaning of } \\
\text { Garnering Festival }\end{array}$ & \\
\hline
\end{tabular}

The whole teaching process is following the four important festivals within Millet Festival, each of the four festivals is combined with a main theme and two to three indigenous knowledge that can be applied to western science. Moreover, students have to learn the worldview contained in each of the festivals. Please see Figure 4 for the actual teaching process of each topic.

\begin{tabular}{|c|c|}
\hline $\begin{array}{l}\text { Constellation and Star Movement } \\
\text { (Reclaiming Festival): } \\
\text { 1. Elders sharing how to tell seasonal change. } \\
\text { 2. Understanding and adjusting star wheel } \\
\text { 3. Discovering star movement regulation. } \\
\text { 4. Finding relationship between bonok and } \\
\text { Seed-sowing season. } \\
\end{array}$ & $\begin{array}{l}\text { Ethno-plant-Soapberry (Seed-sowing } \\
\text { Festival): } \\
\text { 1. Knowing meaning of soapberry. } \\
\text { 2. Knowing its function in daily life. } \\
\text { 3. Knowing bipinnate leaf } \\
\text { 4. Discussing on the eco-cleaning supply. }\end{array}$ \\
\hline $\begin{array}{l}\text { Millet Wine (Harvest Festival): } \\
\text { 1. Elders explaining production method. } \\
\text { 2. Students making Millet Wine. } \\
\text { 3. Discussing how millet turn into wine. } \\
\text { 4. Knowing the significance of garnering and } \\
\text { drinking culture. }\end{array}$ & $\begin{array}{l}\text { Gunpowder (Ear-shooting Festival): } \\
\text { 1. Elders sharing taboos and past experience } \\
\text { 2. Elders sharing prescription for gunpowder.. } \\
\text { 3. Discussing importance of ignition. } \\
\text { 4. Knowing concept of eco-conservation in } \\
\text { traditional hunting activities.. }\end{array}$ \\
\hline
\end{tabular}

Figure 4. The theme and teaching procedure of each ritual in the module

\subsection{Learning Result}

\subsubsection{Enriching Reflection via Bridging Traditional Knowledge and Western Science}

The feature of this module is to make each topic centered on traditional festivals, and to make students learn to link traditional knowledge and western science. According to students' feedback, we could find that their thoughts toward a certain topic were enriched. 
Take the topic on Millet Wine for example. From what students said on the feedback sheet, they used to think that Millet Wine is to simply mix Millet with wine. When the teacher asked, "How to make Millet Wine," the answer was usually "Adding Millet and wine together!" After the teacher's introduction of mukun, and requirement of "healthy students" to chew the cooked millet with students' exclamation, they felt impressed upon ferment mechanism. They learned that wine is produced through the ferment mechanism of millet instead of simply adding wine into millet.

Teacher (as T): Ok, now you all know Millet Wine. Anyone could tell me how to produce millet Wine?

S512: To make it!

T: With wine?

S508: No, with that plant mukun. To make it ferment, chew with teeth, a healthy person to chew it.

S603: Saliva.

T: So traditionally we got mukun and saliva. But how do we do it now?

$S$ (all): Ferment powder!

T: So in order to make wine, what mechanism is needed with millet?

$S$ (all): Fermentation!

3.3.2 Identifying the Value and Significance of Indigenous Culture

For the Constellation and Star Movement topic, students learned that the constellation is from the east to the west, rising east and setting west. They also learned the circular regulation of start signs and how they exercise. The regulation was what indigenous ancestors used to find the best time for Reclaiming. Many students claimed, "How smart our ancestors are!"

The topic on local plants also improves students' identification with their own culture. The following conversation is quoted from the individual interview we did after class. From students' answer, we could see that they learned the meaning of ceremonial rituals and felt proud of their own festivals.

Researcher: If there are guests coming from elsewhere, and you need to introduce Seed-Sowing Festival to them. How would you introduce this festival? What would you say?

S602: I would introduce silver grass and soapberry.

Researcher: Why do you want to introduce these two?

S602: I'd like to let them know that using these two is to expect millet growing as big as soapberry and the stem of millet as strong as silver grass pole.

Moreover, through the comparison with modern environmental pollution, students realize the value and importance of their own traditional culture. Through the traditional cleaning supply, soapberry, the consciousness of living in harmony with nature is thus prominent.

S512: In the class, teacher told us the story of our ancestors. I found that things used by them are natural, not chemical, not polluting the earth.

S510: Yes, that's intelligent and environment-friendly. Good to human beings, and good to the earth too.

\subsubsection{Respecting the Tribal Elders}

Early times, Bunun people taught their children through oral instruction and living experience. Young people learned traditional knowledge and skills passed down from the ancestors. Boys learned to be a good hunter, and learned to tell the weather, direction, and habitual behavior of animals; while girls learned planting and weaving. Through ceremonial rituals, tribal mythology and folk songs were passed on by speaking words (Takewatan, 2007). Thus tribal elders had a very high reputation in traditional tribes. However, under modern education, the mission of passing on knowledge became the job of school teachers. Knowledge taught in school textbooks is far different from Bunun traditional knowledge, resulting in a serious loss of traditional wisdom and culture with the passing of tribal elders. Furthermore, with the influence of modernization and globalization, western science became the only truth. Consequently, traditional knowledge is not taken seriously any more, and the reputation and importance of tribal elders decreased. Thus, one of the tribal elders implied, "The ways used in the past are useless nowadays, so there is no need to teach." School teachers mentioned, "Tribal elder did not have a standard civic education, and the students may think that you don't know the things I learned from school. So they don't expect tribal elders as people did in the past."

But after applying this teaching module, students' attitude towards tribal elders changed. Take the topic on gunpowder for example, students not only learned the necessary condition and ingredients for ignition and explosion, but also 
learned the worldview of obeying Dihanin's law. Bunun people believe that if they could always obey the law of Dihanin to plant and hunt, there would always be Garnering and with fruitful results. On the contrary, without obeying to the law of Dihanin, human beings may not be able to survive. After the instruction of tribal elders, students learned how to tell seasonal change and the habitual behavior of animals. The sharing of hunting experiences and wisdom of tribal elders are not merely an eye-opener to all the students, but to make them more respectful to the elders.

S401: Tribal elders are smarter; they told us what not to do and what to do.

S510: Tribal elders know indigenous culture and can speak indigenous language, so I adore and appreciate.

\section{Discussion and Conclusion}

For a long time, Bunun people have built their own traditional knowledge and established interactive relationship with nature. They do not consider men as the dominator but as equal as any other creatures in nature. This worldview makes Bunun people to be harmony with local environment and animals, which is valuable and worth of passing on to the next generation. At the same when there was no school, traditional knowledge was passed on by story-telling, practical tasks and taboo regulation. Young people also learned and worked out the shared life commitment from fables and legends. However, most adults leave their tribe for work nowadays, leaving school education the main source for children to learn and obtain knowledge. This results in great loss of indigenous culture, so how to develop science courses mixing both traditional indigenous knowledge and western scientific knowledge becomes a serious task for school education. These courses not only provide western scientific explanation for traditional knowledge, but also make traditional knowledge a motivation to understand and learn western science. In short, combining the two kinds of knowledge within recent multicultural scientific education has been an essential goal to achieve.

Ceremonial ritual has great importance and significance in indigenous culture, which links indigenous worldview, social standard and traditional knowledge, and plays a vital role in cultural inheritance. Bunun is a tribe that has a complicated ritual system, and millet growing is considered to be the core of this system. Thus, this study tried to work out a teaching module that is in accordance with Millet Festival, the most important ritual for Bunun community, providing a more flexible and workable for Han teachers and young indigenous teachers to integrate traditional knowledge and western science. Moreover, we invited local elders to participate in school teaching, so as to build a more authentic relationship between young and old for cultural inheritance. Through the elders' participating and sharing traditional knowledge, tribal experience can be taken more seriously in school education. In this way, the goal of "rekindling tradition" (Aikenhead, 2001) can be also achieved. We can see clearly that through the communication between traditional knowledge and western science, students will not only be able to develop ample thoughts upon science-related subjects and topics, but to appreciate their own culture. Also, they learn to respect the tribal elders, and reestablish the channel of cultural succession. From students' performance we could also see that the teaching module did help students' learning science. Last but not the least, this teaching module makes contribution to indigenous cultural inheritance since it has a deeper connection to indigenous worldview through essential rituals. Accordingly, we recommend this teaching module for future science learning courses provided to indigenous students.

\section{Acknowledgements}

This work was supported by grants from the Ministry of Science and Technology, R.O.C. (NSC 101-2511-S-259-004)

\section{References}

Aikenhead, G. S. (2001). Integrating western and aboriginal sciences: Cross-cultural science teaching. Research in Science Education, 31, 337-355. http://dx.doi.org/10.1023/A:1013151709605

Aikenhead, G. S. (2008, Feb). Importation of science programs from Euro-American countries into Asian countries and regions: A recipe for colonization? A keynote paper represented to the Conference of Asian Science Education 2008, Kaohsiung, Taiwan.

http://www.usask.ca/education/profiles/aikenhead/webpage/importation-science-programs.pdf

Aikenhead, G. S., \& Michell, H. (2011). Bridging cultures: Indigenous and scientific ways of knowing nature. Don Mills, Ontario, Canada: Pearson Education.

Bima, D. (1998). The life-related rituals of Taiwan Bunun Tribe. Taipei, Taiwan: Tai-yuen Publisher.

Chang, J. M., Lee, H., \& Yen, C. F. (2010). Alternative conceptions about burning held by Atayal indigene students in Taiwan. International Journal of Science and Mathematics Education, 8, 911-935. http://dx.doi.org/10.1007/s10763-009-9192-9

Chinn, P. W. U. (2007). Decolonizing methodologies and indigenous knowledge: The role of culture, place and personal experience in professional development. Journal of Research in Science Teaching, 44, 1247-1268. http://dx.doi.org/10.1002/tea.20192 
Cobern, W. W., \& Loving, C. C. (2001). Defining science in a multicultural world: Implication for science education. Science Education, 85, 50-67. http://dx.doi.org/10.1002/1098-237X(200101)85:1<50::AID-SCE5>3.0.CO;2-G

Fleer, M. (1997). Science, technology and culture: Supporting multiple world views in curriculum design. Australian Science Teachers Journal, 43(3), 13-18.

Guo, C. J. (2007). Issues in science learning: An international perspective. In S. K. Abell, \& N. G. Lederman (Eds.), Handbook of research on science education (pp. 227-256). Mahwah, NJ: Lawrence Erlbaum Associates.

Hale, J. E. (1994). Unbank the fire: Vision for the education of African American children. Baltimore, MD: Johns Hopkins University Press.

Huang, Y. K. (1989). People's perspectives and the ritual: A case study of the Bunun in Take-Tonpu. Bulletin of the Institute of Ethnology, Academia Sinica, 67, 177-213.

Huang, Y. K. (1991). Dehanin and social crisis: The restudy of religious conversion of the Bunun in Take-Tonpu. Bulletin of the Department of Anthropology, 47, 105-125.

Irzik, G., \& Nola, R. (2009). Worldviews and their relation to science. Science \& Education, 18, 729-745. http://dx.doi.org/10.1007/s11191-007-9087-5

Jegede, O. J., \& Okebukola, P. A. (1991). The effect of instruction on socio-cultural belief hindering the learning of science. Journal of Research in Science Teaching, 28, 275-285. http://dx.doi.org/10.1002/tea.3660280308

Kearney, M. (1984). World view. Novato, CA: Chandler \& Sharp.

Lee, H. (2013). The development of indigenous science education research in Taiwan. Paper presented at Global Chinese Conference on Science Education 2013, Guang Zhou, China.

Lee, H., Chiang, C. L., \& Lin, Y. C. (2011, Jul). Bunun's worldview of Nature and its influence on daily life. Paper presented at the 11th International IHPST and 6th Greek History, Philosophy and Science Teaching Joint Conference, Thessaloniki, Greece. Abstract retrieved from http://ihpst2011.eled.auth.gr/ihpst2011_book_of_abstracts

McKinley, E. (2005). Locating the global: Culture, language and science education for indigenous students. International Journal of Science Education, 27, 227-241. http://dx.doi.org/10.1080/0950069042000325861

McKinley, E. (2007). Postcolonialism, indigenous students, and science education. In S. K. Abell, \& N. G. Lederman (Eds.), Handbook of Research on Science Education (pp. 199-226). Mahwah, NJ: Lawrence Erlbaum.

Ming, L. G. (1989). The indigenous sacrificial rites in Taiwan. Taipei, Taiwan: Tai-yuen Publisher.

Ogawa, M. (1989). Beyond the tacit framework of 'science' and 'science education' among science educators. International Journal of Science Education, 11, 247-250. http://dx.doi.org/10.1080/0950069890110301

Sutherland, D. L. (1998). Aboriginal students' perception of the nature of science: The influence of culture, language and gender (Unpublished Ph.D. dissertation). University of Nottingham, Nottingham, UK.

Tsi, W. S. (2006). The study of conferring the problems and solutions of aboriginal students' education in Taiwan. Journal of the National Institute for Compilation and Translation, 34(3), 21-34.

Vava, H. (2002). The guard of the Central Range: Bunun. Taipei, Taiwan: Daohsiang Publisher.

Yang, S. Y. (2006). Personhood, ritual healing and social change: The example of the Bunun. Taiwan Journal of Anthropology, 4(2), 75-111.

Yu, J. H., \& Ouyang, Y. (2002). Myths, rituals, and the Bunun. Taichung, Taiwan: Morning Star Publisher.

\section{$(\mathrm{cc}) \mathrm{Br}$}

This work is licensed under a Creative Commons Attribution 3.0 License. 